\title{
Correlation between Apoptosis and in Situ Immune Response in Fatal Cases of Microcephaly Caused by Zika Virus
}

Jorge R. de Sousa, ${ }^{*}$ Raimunda S.S. Azevedo, ${ }^{*}$ Arnaldo J. Martins Filho, ${ }^{\dagger}$ Marialva T.F. Araujo, ${ }^{\dagger}$ Ermelinda R.C. Moutinho, Barbara C. Baldez Vasconcelos, ${ }^{\ddagger}$ Ana C.R. Cruz, ${ }^{*}$ Consuelo S. Oliveira, ${ }^{*}$ Lívia C. Martins, ${ }^{*}$ Beatriz H. Baldez Vasconcelos, Livia M.N. Casseb, ${ }^{*}$ Jannifer 0. Chiang, ${ }^{*}$ Juarez A.S. Quaresma, ${ }^{\dagger \dagger \S}$ and Pedro F.C. Vasconcelos ${ }^{* \ddagger}$

From the Departments of Arbovirology and Hemorrhagic Fevers* and Pathology, ${ }^{\dagger}$ Evandro Chagas Institute, Ministry of Health, Ananindeua; the Center of Biological and Health Sciences, ${ }^{\ddagger}$ State University of Pará, Belém; and the Tropical Medicine Center, ${ }^{\S}$ Federal University of Pará, Belém, Brazil

Accepted for publication

July 16, 2018.

Address correspondence to Pedro F.C. Vasconcelos, M.D., Ph.D., Department of Arbovirology and Hemorrhagic Fevers; or Juarez A.S. Quaresma, M.D., Ph.D., Department of Pathology, Evandro Chagas Institute, Ministry of Health, Rodovia BR-316, km-07, s/n, Ananindeua 67030-000, Brazil. E-mail: pedrovasconcelos@ iec.gov.br or juarez@ufpa.br.

\begin{abstract}
Zika virus (ZIKV) is a single-stranded positive-sense RNA flavivirus that possesses a genome approximately $10.7 \mathrm{~Kb}$ in length. Although pro-inflammatory and anti-inflammatory cytokines and apoptotic markers belonging to the extrinsic and intrinsic pathways are suggested to be involved in fatal cases of ZIKV-induced microcephaly, their exact roles and associations are unclear. To address this, brain tissue samples were collected from 10 individuals, five of whom were diagnosed as ZIKV positive with microcephaly and a further five were flavivirus-negative controls that died because of other causes. Examination of material from the fatal cases of microcephaly revealed lesions in the cerebral cortex, edema, vascular proliferation, neuronal necrosis, gliosis, neuronophagy, calcifications, apoptosis, and neuron loss. The expression of various apoptosis markers in the neural parenchyma, including FasL, FAS, $\mathrm{BAX}, \mathrm{BCL2}$, and caspase 3 differed between ZIKV-positive cases and controls. Further investigation of type 1 and 2 helper T-cell cytokines confirmed a greater anti-inflammatory response in fatal ZIKV-associated microcephaly cases. Finally, an analysis of the linear correlation between tumor necrosis factor- $\alpha$, IL-1 $\beta$, IL-4, IL-10, transforming growth factor- $\beta$, and IL-33 expression and various apoptotic markers suggested that the immune response may be associated with the apoptotic phenomenon observed in ZIKV-induced microcephaly. (Am J Pathol 2018, 188: 2644-2652; https:// doi.org/10.1016/j.ajpath.2018.07.009)
\end{abstract}

Zika virus (ZIKV) is a member of the single-stranded positive-sense RNA virus Flaviviridae family ${ }^{1}$ that was first isolated from the blood of a rhesus macaque (Macaca mulatta) in 1947 in the Zika Forest, Uganda, during a sentinel study. ${ }^{2}$ Like many other flaviviruses, ZIKV was initially thought to be transmitted solely through the bite of infective mosquitoes of the Aedes genus (primarily Aedes aegypti in tropical regions). Recently, however, ZIKV has been found to be transmissible via congenital and sexual routes, ${ }^{3}$ and to infect a wide group of cells across different organs and tissues. ${ }^{4}$ The symptoms presented during infection are similar to those presented by other viruses, such as dengue (DENV) and chikungunya, although ZIKV is defined by an abrupt onset of mild fever, myalgia, rash, conjunctival hyperemia, joint edema, and headache.
In recent years, ZIKV has become a global concern because of increased incidences of Guillain-Barré syndrome, microcephaly, and other congenital malformations. ${ }^{1}$ In 2007, ZIKV was first reported outside of its original endemic area during an outbreak on Yap Island, Federated States of Micronesia. ${ }^{6,7}$ By October 2013, ZIKV had reached French Polynesia in the South Pacific, and by April 2014, an estimated 30,000 individuals were infected. ${ }^{8,9}$ In

Supported by the Ministry of Science, Technology and Innovation/ National Council for Scientific and Technological Development CNPQ, Brazil grants 303999/2016-0, 439971/2016-0, and 440405/2016-5 and Coordination for the Improvement of Higher Level Personnel (CAPES), Brazil (Zika Fast-Track) (P.F.C.V.).

P.F.C.V. and J.A.S.Q. contributed equally to this work.

Disclosures: None declared. 
2015, there was an outbreak in Brazil, with estimated ZIKV cases ranging from 440,000 to $1,300,000{ }^{10,11}$ Accordingly, an increase in the number of Guillain-Barré syndrome cases was also reported in the country. More important, higher rates of microcephaly in neonates and greater mortality in patients with autoimmune disorders were directly associated with ZIKV infection for the first time during the outbreak. $^{12,13}$

Since the identification of this association, research has been undertaken to understand the development of microcephaly in neonates and the role of the immune response in ZIKV pathogenesis. ${ }^{1,14}$ It is currently believed that the first cells infected by ZIKV in the brain are astrocytes, microglial cells, and neural progenitor cells. Infection of these cells may be facilitated by the presence of T-cell/transmembrane, Ig, and mucin and Tyro3, AXL, and Mertk receptors that mediate ZIKV entry, particularly the receptor tyrosine kinase AXL. ${ }^{1,15}$ However, the exact mechanisms involved in ZIKV infection, especially the entry pathway, remain unclear and somewhat controversial. Indeed, it has recently been shown that AXL may not be essential for ZIKV entry into cells of the central nervous system (CNS). Instead, AXL may promote ZIKV infection in astrocytes by antagonizing type I interferon signaling. ${ }^{16}$

With regards to the development of microcephaly, apoptosis appears to contribute to pathology via the elimination of infected cells, with little tissue damage. ${ }^{17,18}$ Because of the close relationship between the immune response and apoptosis, activation of various death receptors, including the first apoptosis signal receptor (FAS) and tumor necrosis factor- $\alpha$ receptor, can induce activation of FAS-associated protein with death domain (alias MORT1) and tumor necrosis factor receptor type 1 -associated death domain proteins. Such activation can lead to the development of a caspase cascade that culminates in programed cell death. ${ }^{19,20}$ In particular, toll-like receptor 3 has been shown to recognize pathogenassociated molecular patterns specific to ZIKV, leading to deregulation of the cellular cycle and activation of proapoptotic genes. After expression, these proteins promote the death of progenitor neurons. ${ }^{21}$ In the brain, and primarily the cerebral cortex, increased expression of caspase 3 has been shown to associate with the death of cortical neurons. ${ }^{1}$

Despite these many studies, a full understanding of the roles of pro-inflammatory and anti-inflammatory cytokines, and apoptotic markers, in the pathogenesis of ZIKV remains unclear. Therefore, our study examined apoptosis and the in situ immune response in the neural parenchyma of fatal cases of microcephaly caused by ZIKV relative to uninfected controls. These data were used to investigate the mechanisms and associations that may underlie cell injury because of the virus. We also examined the relationship between in situ apoptosis markers and the expression of various type 1 and 2 helper T-cell cytokines, in addition to any gross changes in histopathology.

\section{Materials and Methods}

\section{Ethics Statement}

Patient samples were collected and processed under an emergency context during the recent ZIKV epidemic, defined by the Ministry of Health, Brazil. The study was approved by the research human ethic committee of the Evandro Chagas Institute, Brazil (opinion number 1.888.946).

\section{Patients, Samples, and Diagnosis of ZIKV Infection}

In total, 10 patients were included in the study. Five comprised the ZIKV-positive group and presented with microcephaly (three were neonates, whereas two were stillbirths). The control group consisted of two newborns and three stillbirths who had no evidence of ZIKV infection, nor that of any other flavivirus or alfavirus infections that circulate in Brazil, such as DENV, yellow fever virus, and chikungunya. Each of the five patients of the control group had preserved neural architecture samples suitable for comparison with the ZIKV group. All control group samples were submitted to the same laboratory tests of the patients [ie, real-time quantitative RT-PCR (RT-qPCR), attempts of virus isolation or cell culture, and immunohistochemical assay]. All cases were obtained during the ZIKV epidemic in Brazil in 2016. Detailed information on patients and controls is shown in Table 1.

\section{Real-Time RT-qPCR and Virus Isolation}

Viruses were initially isolated using C6/36 cell culture, as described in a previous study. ${ }^{22}$ Briefly, a solution of phosphate-buffered saline containing $10 \%$ fetal bovine serum and antibiotics was used to triturate the blood and tissue samples. Next, $100-\mu \mathrm{L}$ aliquots of each supernatant were inoculated into $25-\mathrm{cm}^{2}$ tissue culture flasks preseeded with a monolayer of C6/36 Aedes albopictus cells. After 2 hours' incubation at $28^{\circ} \mathrm{C}$, more medium was added and the cells were incubated at room temperature (approximately $25^{\circ} \mathrm{C}$ ) for 10 days. ZIKV RNA was detected by real-time RT-qPCR using a previously described protocol. ${ }^{23,24}$ For the final assessment, RNA was isolated from tissue homogenate supernatants and sera using a TRIzol Plus RNA Extraction Kit (Ambion; Thermo Fisher Scientific, Waltham, MA), according to the manufacturer's instructions. Real-time RT-qPCR was performed using a 7500 Real Time PCR System (Thermo Fisher Scientific) and a Superscript III Platinum One-Step RT-qPCR Kit (Thermo Fisher Scientific). The detection of specific regions of the ZIKV genome was performed using various primer/probe sets that targeted the $N S 5^{23}$ and $E^{24}$ sequences. Real-time PCR was performed independently for all cases, despite cell culture results obtained during attempts of virus isolation. In general, the specimens sent to RT-PCR were blood and CNS tissue samples. All CNS 
Table 1 Details and Distributions of ZIKV-Positive Microcephaly Cases and Controls without Evidence of ZIKV Infection

\begin{tabular}{|c|c|c|c|c|c|c|}
\hline Case & Category & Lifetime & Sex & Case information & IHC (ZIKV) & $\begin{array}{l}\text { Real-time } \\
\text { RT-qPCR (ZIKV) }\end{array}$ \\
\hline \multicolumn{7}{|c|}{ Microcephaly } \\
\hline 1 & Newborn & 2 hours & M & $\begin{array}{l}\text { Microcephaly and other malformations } \\
\text { (nasopalatine palate and sindactyly, club foot) }\end{array}$ & Positive & Negative \\
\hline 2 & Newborn & 27 days & M & Microcephaly and other congenital malformations & Positive & Positive \\
\hline 3 & Newborn & 2 days & M & Microcephaly & Positive & Negative \\
\hline 4 & Stillbirth & NA & $\mathrm{F}$ & Microcephaly detected at birth & Positive & NR \\
\hline 5 & Stillbirth & NA & $\mathrm{F}$ & Microcephaly & Positive & Negative \\
\hline \multicolumn{7}{|c|}{ Control } \\
\hline 6 & Newborn & 10 days & $\mathrm{F}$ & $\begin{array}{l}\text { No microcephaly; death } 10 \text { days after birth without } \\
\text { evidence of ZIKV infection }\end{array}$ & Negative & Negative \\
\hline 7 & Stillbirth & NA & M & Microcephaly without evidence ZIKV infection & Negative & Negative \\
\hline 8 & Stillbirth & NA & $\mathrm{F}$ & Microcephaly without evidence ZIKV infection & Negative & NR \\
\hline 9 & Stillbirth & NA & $\mathrm{F}$ & Microcephaly without evidence ZIKV infection & Negative & NR \\
\hline 10 & Newborn & 19 hours & $\mathrm{F}$ & $\begin{array}{l}\text { Microcephaly case without evidence of ZIKV infection; mother } \\
\text { with hyperthyroidism and pregnancy-induced by hypertension }\end{array}$ & Negative & Negative \\
\hline
\end{tabular}

F, female; M, male; IHC, immunohistochemistry; NA, not applicable; NR, not performed; RT-qPCR, quantitative RT-PCR; ZIKV, Zika virus.

specimens were obtained from autopsy performed in the place of the case report. For all laboratory protocols, the patient and control samples were run together in the same assay, which in general were performed in triplicate. Mother samples were not equally received.

\section{Histopathology and Immunohistochemistry}

To avoid autolysis of the tissue, immediately after autopsy, the material was conserved in $10 \%$ neutral-buffered formalin to be processed. For the histopathological analysis, sections ( $5 \mu \mathrm{m}$ thick) were cut from paraffin-embedded tissue samples and stained with hematoxylin and eosin. The immunohistochemical study used a streptavidin-alkaline phosphatase method that was adapted to detect viral antigens using a polyclonal anti-ZIKV antibody produced by the Evandro Chagas Institute/Ministry of Health, Brazil. ${ }^{13}$ It is important to emphasize that in serologic tests, the ZIKV-antibody presents cross-reactivity mainly with DENV; however, in the immunohistochemical assays, the reaction was clearly monotypic to ZIKV-antibody in the tissues and cross-reactivity with other flaviviruses, such as DENV and yellow fever virus, was not observed.

The investigation of apoptosis markers and cytokines (Table 2) was based on a previously published biotinstreptavidin-peroxidase method. ${ }^{25}$ Briefly, histologic sections were first deparaffinized in xylene and hydrated in a decreasing ethanol series $(90 \%, 80 \%$, and $70 \%)$. Endogenous peroxidase was then blocked with $3 \%$ hydrogen peroxide for 45 minutes. Finally, antigenic recovery was performed using a citrate buffer ( $\mathrm{pH}$ 6.0) for 20 minutes at $90^{\circ} \mathrm{C}$. Nonspecific protein interactions were blocked by incubating the sections in $10 \%$ skim milk for 30 minutes. Histologic sections were incubated overnight with primary antibodies (Abcam, Paris, France) diluted in 1\% bovine serum albumin (Table 2). Next, the slides were immersed in $1 \times$ phosphate-buffered saline and incubated with a secondary biotinylated antibody (labeled streptavidin-biotin; DakoCytomation, Glostrup, Denmark) in an oven for 30 minutes at $37^{\circ} \mathrm{C}$. The slides were then again immersed in $1 \times$ phosphate-buffered saline and incubated with streptavidin peroxidase (labeled streptavidin-biotin) for 30 minutes at $37^{\circ} \mathrm{C}$. Finally, the reactions were developed with $0.03 \%$ diaminobenzidine and $3 \%$ hydrogen peroxide as a chromogenic solution. The slides were washed in distilled water and counterstained with Harris hematoxylin for 1 minute before being dehydrated in an increasing ethanol series and cleared in xylene.

\section{Quantitative Analysis and Image Documentation}

Histologic sections were analyzed using an Axio Imager Z1 microscope (Zeiss, Oberkochen, Germany). Quantification

Table 2 Antibodies Used in the Study of Apoptosis and Immune Response in Fatal Cases of ZIKV-Associated Microcephaly

\begin{tabular}{lll}
\hline Markers & Reference & Dilution \\
\hline FasL & Abcam (Ab 15285) & $1: 50$ \\
FAS & Abcam (Ab 82419) & $1: 50$ \\
BAX & Abcam (Ab 32503) & $1: 50$ \\
BCL2 & Abcam (Ab 59348) & $1: 50$ \\
RIP1 & Abcam (Ab 72139) & $1: 50$ \\
Caspase 3 & Abcam (Ab 4051) & $1: 50$ \\
TNF- $\alpha$ & Abcam (Ab 6671) & $1: 50$ \\
IL-1 $\beta$ & Abcam (Ab 9722) & $1: 50$ \\
IL-4 & Abcam (Ab 9622) & $1: 50$ \\
IL-10 & Abcam (Ab 34843) & $1: 50$ \\
TGF- $\beta$ & Abcam (Ab 190503) & $1: 50$ \\
IL-33 & Abcam (Ab 118503) & $1: 50$ \\
\hline
\end{tabular}

TGF- $\beta$, transforming growth factor- $\beta$; TNF- $\alpha$, tumor necrosis factor- $\alpha$; ZIKV, Zika virus. 


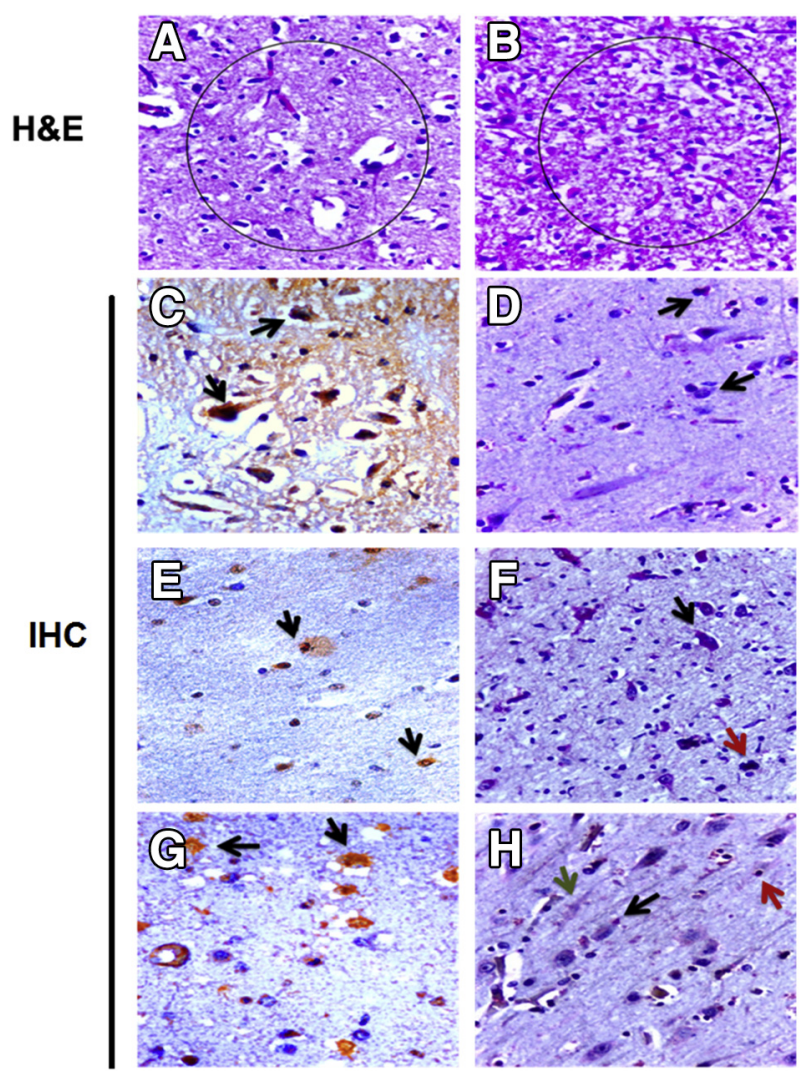

Figure 1 Histopathology and Zika virus (ZIKV) immunohistochemistry in the neural parenchyma of fatal ZIKV microcephaly cases. A-D: Analysis reveals areas of edema and vascular proliferation (circles; $\mathbf{A}$ and $\mathbf{B}$ ), edema and neuronal necrosis (arrows; C), and neuronophagy (arrows; D). E and F: Immunolabeling of ZIKV antigens is found in microglial cells (E) and neurons (black arrows) with calcification (red arrow; F). G: ZIKV antigens are also detected in astrocytes (black arrows). H: Finally, apoptotic neurons (black arrow) and neuronal loss (green arrow), and neuronophagy with neuronal loss (red arrow), are identified. Original magnification, $\times 400$. H\&E, hematoxylin and eosin; IHC, immunohistochemistry.

of staining was assessed across a random selection of 10 fields at high magnification $(\times 400)$ from the parenchyma of the cerebral cortex of ZIKV-positive or ZIKV-negative cases. Each field was subdivided into $10 \times 10$ areas, delimited by a grid that comprised an area of $0.0625 \mathrm{~mm}^{2}$.

\section{Statistical Analysis}

Statistical analysis was performed in GraphPad Prism 5.0 (GraphPad, La Jolla, CA) using $t$-tests and Pearson's correlation tests. For both tests, the threshold level of significance was set at $5 \%(P \leq 0.05)$.

\section{Results}

Description of the Main Histopathological Alterations and Distribution of Viral Antigen in Neonates with Fatal ZIKV-Associated Microcephaly

An initial analysis of the intraparenchymal environment showed various differences in brain structure between
ZIKV-infected and control samples. Specifically, there were lesions in the cerebral cortex of fatal cases of ZIKVassociated microcephaly, in addition to edema and vascular proliferation (Figure 1, A and B), neuronal necrosis (Figure 1C), gliosis, neuronophagy (Figure 1D), calcifications (Figure $1 \mathrm{~F}$ ), apoptosis (Figure $1 \mathrm{H}$ ), and neuron loss, suggestive of neuronophagy (Figure $1 \mathrm{H}$ ). Detection of viral antigen revealed that ZIKV infected several different cell types in the neural parenchyma, including neurons and glial cells (Figure 1, C-H).

Expression of Apoptotic Markers and Pro-Inflammatory and Anti-Inflammatory Cytokines in the Neural Parenchyma in Fatal Cases of ZIKV-Associated Microcephaly

The study of different markers for apoptosis, including FasL, FAS, BAX, BCL2, RIP1, and caspase 3, showed that extrinsic and intrinsic pathways are activated, where expression of proteins (FasL, FAS, BAX, BCL2, and RIP1) and caspase 3 is more intense in ZIKV-positive cases compared with the control (Table 3 and Figure 2).

The expression of several cytokines was also analyzed in the neural parenchyma, including IL- $1 \beta$, TNF- $\alpha$, IL-4, IL10 , transforming growth factor (TGF)- $\beta$, and IL-33. This demonstrated statistically significant differences in the expression of both pro-inflammatory (IL-1 $\beta$ and TNF- $\alpha$ ) (Figure 3) and anti-inflammatory cytokines between cases and controls (Table 3 and Figure 3). Immunostaining for type 2 helper T-cell cytokines (IL-4, IL-10, TGF- $\beta$, and IL-33) was more intense in areas of the cerebral cortex where histopathology revealed extensive cell damage, particularly for IL-33 (Figure 3). Finally, a correlation analysis indicated a positive association between the FasL/FAS, BAX/BCL2, and caspase 3 markers and

Table 3 Quantitative Analysis of Apoptotic Markers and Cytokines in the Neural Parenchyma of Fatal ZIKV-Associated Microcephaly Cases Compared with Controls

\begin{tabular}{llrl}
\hline Markers & Parenchyma & \multicolumn{1}{l}{ Control } & $P$ value \\
\hline FasL & $14.60 \pm 2.702$ & $5.000 \pm 2.550$ & $0.0004^{* * * *}$ \\
FAS & $15.80 \pm 0.836$ & $4.200 \pm 1.924$ & $0.0001^{* * * *}$ \\
BAX & $15.00 \pm 1.871$ & $6.800 \pm 2.387$ & $0.0003^{* * * *}$ \\
BCL2 & $10.80 \pm 1.483$ & $5.600 \pm 2.074$ & $0.0018^{* * *}$ \\
RIP1 & $17.40 \pm 3.782$ & $7.000 \pm 3.536$ & $0.0020^{* * *}$ \\
Caspase 3 & $25.20 \pm 5.215$ & $6.400 \pm 2.966$ & $0.0001^{* * * *}$ \\
TNF- $\alpha$ & $31.20 \pm 4.147$ & $11.40 \pm 2.881$ & $0.0001^{* * * *}$ \\
IL-1 $\beta$ & $28.00 \pm 1.581$ & $9.400 \pm 2.881$ & $0.0001^{* * * *}$ \\
IL-4 & $35.40 \pm 2.966$ & $9.600 \pm 4.615$ & $0.0001^{* * * *}$ \\
IL-10 & $40.20 \pm 3.114$ & $9.000 \pm 4.743$ & $0.0001^{* * * *}$ \\
TGF- $\beta$ & $33.20 \pm 1.304$ & $6.600 \pm 2.702$ & $0.0001^{* * * *}$ \\
IL-33 & $52.40 \pm 2.510$ & $11.00 \pm 1.581$ & $0.0001^{* * * *}$ \\
\hline
\end{tabular}

$* * * P<0.001, * * * * P<0.0001$ (t-test).

TGF- $\beta$, transforming growth factor- $\beta$; TNF- $\alpha$, tumor necrosis factor- $\alpha$; ZIKV, Zika virus. 


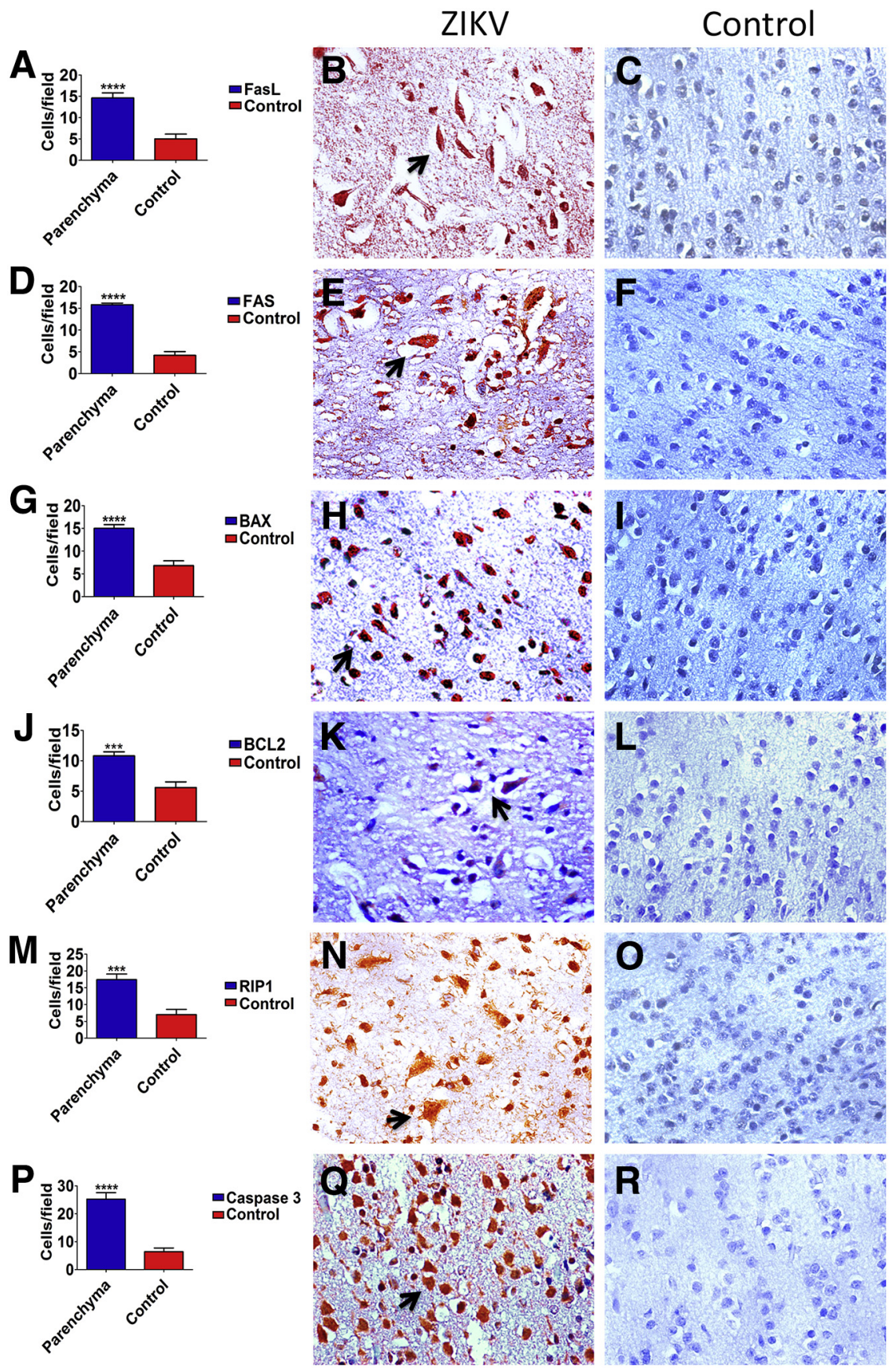

Figure 2 Quantitative analysis and immunohistochemistry of apoptosis markers in fatal cases of Zika virus (ZIKV)-associated microcephaly and controls. Comparative analysis to expression of FasL in the neural parenchyma in ZIKV-positive cases and control (A), positive immunolabeling to FasL in neuron (arrow; B), and control (C). Comparative analysis to expression of FAS in the neural parenchyma in ZIKV-positive cases and control (D), positive immunolabeling in neuron to FAS (arrow; E), and control (F). Comparative analysis to expression of BAX in the neural parenchyma in ZIKV-positive cases and control (G), positive immunolabeling to $\mathrm{BAX}$ in microglia (arrow; H), and control (I). Comparative analysis to expression of $\mathrm{BCL} 2$ in the neural parenchyma in ZIKV-positive cases and control (J), positive immunolabeling to BCL2 in neuron (arrow; K), and control (L). Comparative analysis to expression of RIP1 in the neural parenchyma in ZIKV-positive cases and control (M), positive immunolabeling to RIP1 in neuron (arrow; N), and control (0). Comparative analysis to expression of caspase 3 in the neural parenchyma in ZIKV-positive cases and control (P), positive immunolabeling to caspase 3 in neuron (arrow; $\mathbf{Q}$ ), and control (R). $* * * P<0.001, * * * * P<0.0001$ versus control (t-test). Original magnification, $\times 400(B, C, E, F$, $\mathbf{H}, \mathbf{I}, \mathbf{K}, \mathbf{L}, \mathbf{N}, \mathbf{0}, \mathbf{Q}$, and $\mathbf{R}$ ).

pro-inflammatory and anti-inflammatory cytokines in the neural parenchyma (Table 4).

\section{Discussion}

ZIKV is a flavivirus that causes severe pathology in neonates, including tissue damage in the CNS and microcephaly. ${ }^{26-30}$ To this end, our data indicate that apoptosis may contribute to these processes by inducing cell death in neurons and glial cells of the neural parenchyma. We have also shown that apoptotic marker expression correlates with cytokine expression and increased cellular damage in the neural parenchyma during fatal ZIKV-associated microcephaly, suggesting a possible functional link (Table 4). Previously, studies on FasL and FAS have shown that these proteins initiate an apoptotic cascade during flavivirus infections, and the binding of FasL-FAS induces the recruitment of adaptor proteins, activation of death domains, and activation of caspases. ${ }^{31,32}$ We hypothesize that these FasL/FAS interactions may be associated with responses mediated by BCL2 family members essential for the 


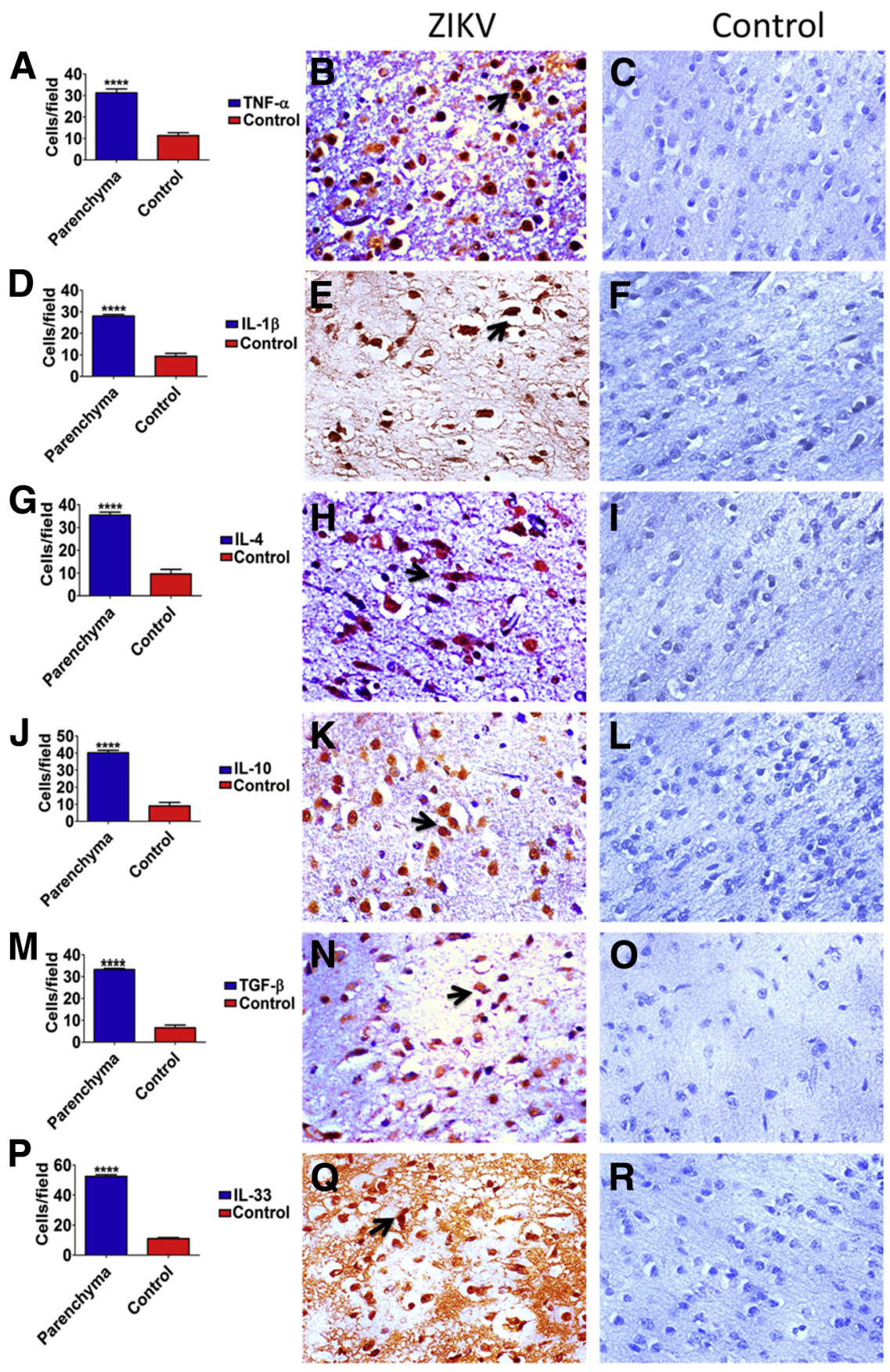

Figure 3 Quantitative analysis and immunohistochemistry of cytokines in fatal cases of Zika virus (ZIKV)-associated microcephaly and controls. Comparative analysis to expression of tumor necrosis factor (TNF)- $\alpha$ in the neural parenchyma in ZIKV-positive cases and control (A), positive immunolabeling to TNF- $\alpha$ in oligodendrocyte (black arrow; B), and control (C). Comparative analysis to expression of IL-1 $\beta$ in the neural parenchyma in ZIKV-positive cases and control (D), positive immunolabeling to IL-1 $\beta$ in neuron (black arrow; E), and control (F). Comparative analysis to expression of IL-4 in the neural parenchyma in ZIKV-positive cases and control (G), positive immunolabeling to IL-4 in neuron (black arrow; H), and control (I). Comparative analysis to expression of IL-10 in the neural parenchyma in ZIKV-positive cases and control (J), positive immunolabeling to IL-10 in oligodendrocyte (black arrow; K), and control (L). Comparative analysis to expression of transforming growth factor (TGF)- $\beta$ in the neural parenchyma in ZIKVpositive cases and control (M), positive immunolabeling to TGF- $\beta$ in neuron (black arrow; $\mathbf{N}$ ), and control (0). Comparative analysis to expression of IL-33 in the neural parenchyma in ZIKV-positive cases and control ( $\mathbf{P})$, positive immunolabeling to IL-33 in neuron (black arrow; $\mathbf{Q}$ ), and control $(\mathbf{R}) .{ }^{* * *} P<0.0001$ versus control (t-test).

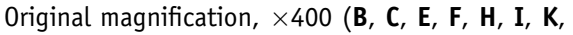
$\mathbf{L}, \mathbf{N}, \mathbf{0}, \mathbf{Q}$, and $\mathbf{R})$.

regulation of the intrinsic apoptosis pathway, such as BAX and BCL2. Notably, BAX has been shown to induce mitochondrial damage and the formation of transmembrane pores, leading to the release of cytochrome $c$ that binds to apoptotic protease activating factor 1 to form apoptosomes. ${ }^{32,33}$ In contrast, the negative effects of BCL2 in the intrinsic pathway cause inhibition of the apoptotic cascade, preventing the formation of apoptosomes. Using experimental mouse models, ZIKV has previously been shown to activate genes responsible for the production of Bax and $B c l-2$, indicating a putative relationship. ${ }^{34,35}$
Our study has also revealed that RIP1 expression differed in the neural parenchyma of fatal cases of ZIKV-associated microcephaly (Table 3 and Figure 2). RIP1 is a protein kinase that modulates cellular injury by inducing NF- $\kappa \mathrm{B}$ production, as well as other inflammatory markers. ${ }^{36,37}$ When phosphorylated, the protein causes the degradation of several complexes, leading to the subsequent release and activation of caspase 8, an important initiator of the apoptotic cascade. ${ }^{36-38}$ The increase in RIP1 expression in the neural parenchyma suggests that an apoptotic response is occurring through various pathways, such as tumor 
Table 4 Linear Correlation between Markers of Apoptosis and Cytokines in Fatal ZIKV-Associated Microcephaly Cases

\begin{tabular}{|c|c|c|}
\hline Correlation & $r$ value & $P$ value \\
\hline FasL $\times$ FAS & 0.5087 & 0.3814 \\
\hline FasL $\times$ BAX & 0.8903 & $0.0429^{*}$ \\
\hline FasL $\times$ BCL2 & -05864 & 0.2986 \\
\hline FasL $\times$ caspase 3 & 0.6813 & 0.2053 \\
\hline FAS $\times$ caspase 3 & 0.6417 & 0.2431 \\
\hline $\mathrm{BAX} \times \mathrm{BCL} 2$ & -0.7207 & 0.1695 \\
\hline BAX $\times$ caspase 3 & 0.6918 & 0.1955 \\
\hline $\mathrm{BCL} 2 \times \mathrm{RIP} 1$ & -0.7399 & 0.1528 \\
\hline BCL2 $\times$ caspase 3 & -0.8984 & $0.0382^{*}$ \\
\hline RIP $1 \times$ caspase 3 & 0.8062 & 0.0993 \\
\hline TNF- $\alpha \times$ FasL & 0.9237 & $0.0250^{*}$ \\
\hline TNF- $\alpha \times$ FAS & 0.5908 & 0.2941 \\
\hline TNF- $\alpha \times$ BAX & 0.8378 & 0.0765 \\
\hline TNF- $\alpha \times$ RIP1 & 0.5037 & 0.3869 \\
\hline TNF- $\alpha \times$ caspase 3 & 0.8992 & $0.0378 *$ \\
\hline IL-1 $\beta \times$ FasL & 0.8778 & 0.0503 \\
\hline $\mathrm{IL}-1 \beta \times \mathrm{FAS}$ & 0.7559 & 0.1393 \\
\hline $\mathrm{IL}-1 \beta \times \mathrm{BAX}$ & 0.6761 & 0.2101 \\
\hline IL-1 $\beta \times$ caspase 3 & 0.8489 & 0.0689 \\
\hline $\mathrm{IL}-4 \times$ FasL & 0.5240 & 0.3647 \\
\hline $\mathrm{IL}-4 \times$ FAS & 0.8461 & 0.0707 \\
\hline $\mathrm{IL}-4 \times \mathrm{BAX}$ & 0.5406 & 0.3469 \\
\hline $\mathrm{IL}-4 \times \mathrm{RIP} 1$ & 0.8736 & 0.0529 \\
\hline IL- $4 \times$ caspase 3 & 0.8984 & 0.0689 \\
\hline IL-10 $\times$ FasL & 0.5764 & 0.3090 \\
\hline $\mathrm{IL}-10 \times$ FAS & 0.6908 & 0.1965 \\
\hline $\mathrm{IL}-10 \times \mathrm{BAX}$ & 0.7294 & 0.1619 \\
\hline $\mathrm{IL}-10 \times \mathrm{RIP} 1$ & 0.8618 & 0.0603 \\
\hline IL-10 $\times$ caspase 3 & 0.7973 & 0.1061 \\
\hline TGF- $\beta \times$ FAS & 0.5042 & 0.3864 \\
\hline TGF- $\beta \times$ RIP1 & 0.7403 & 0.1525 \\
\hline TGF- $\beta \times$ caspase 3 & 0.8382 & 0.0761 \\
\hline $\mathrm{IL}-33 \times$ FasL & 0.8036 & 0.1013 \\
\hline $\mathrm{IL}-33 \times \mathrm{BAX}$ & 0.9583 & $0.0101^{*}$ \\
\hline IL-33 × RIP1 & 0.6901 & 0.1971 \\
\hline IL-33 $\times$ caspase 3 & 0.8327 & 0.0800 \\
\hline TNF- $\alpha \times$ IL-1 $\beta$ & 0.9531 & $0.0121^{*}$ \\
\hline $\mathrm{IL}-4 \times \mathrm{IL}-10$ & 0.9092 & $0.0324^{*}$ \\
\hline $\mathrm{IL}-10 \times \mathrm{IL}-33$ & 0.8507 & 0.0676 \\
\hline $\mathrm{IL}-4 \times \mathrm{IL}-33$ & 0.7112 & 0.1774 \\
\hline
\end{tabular}

$* P<0.05$ (Pearson correlation).

TGF- $\beta$, transforming growth factor- $\beta$; TNF- $\alpha$, tumor necrosis factor- $\alpha$; ZIKV, Zika virus.

necrosis factor receptor type 1-associated death domain and FAS-associated protein with death domain. Our in situ study also shows that expression of caspase 3 was elevated in certain areas of the cerebral cortex, indicating that caspase 3 expression is high in the neural parenchyma, even in the presence of BCL2. This further supports the involvement of these proteins and apoptosis in cases of fatal ZIKVassociated microcephaly. Prior in vitro models have also shown that there is an inverse correlation between the production of caspase 3 and the number of cortical neurons in the cortical layer, and that an increase in expression directly contributes to a reduction in the cortical neuron population. ${ }^{1,2}$

Previously, it has been shown that the immune response to ZIKV is an important contributor to virus-associated pathogenic changes in neural tissues. ${ }^{1}$ Our current study supports this suggestion, and significant differences were found in the levels of pro-inflammatory cytokines (IL-1 $\beta$ and TNF- $\alpha$ ) between cases and controls (Table 3 and Figure 2). The presence of these proteins in the neural parenchyma may indicate their involvement in the triggering of a lytic response and the neuroinflammation that occurs during fatal cases of ZIKV-associated microcephaly. In particular, TNF- $\alpha$ has been strongly associated with cell death through the binding of $\mathrm{TNF}-\alpha$ to $\mathrm{TNF}-\alpha$ receptor. Interactions between TNF- $\alpha$ and $\mathrm{TNF}-\alpha$ receptor can also induce the activation of tumor necrosis factor receptor type 1 -associated death domain and FAS-associated protein with death domain, initiating an apoptotic intracellular cascade. $^{39-41}$ Cell damage attributable to IL- $1 \beta$ and TNF- $\alpha$ may be important during the ZIKV-mediated neuroinflammatory response, and these cytokines are rapidly produced by brain tissue after acute injury in other classic neurodegenerative diseases. ${ }^{42,43}$ IL-1 $\beta$ has also been demonstrated to be directly associated with the inflammasome response, oxidative stress, and cell death. During ZIKV infection, the activation of inflammasomes in glial cells induces the production of NACHT, LRR, NLRP3, caspase 1 , and IL-1 $\beta .^{44}$ In addition, the expression of these markers intensifies the neuroinflammatory response and leads to the production of reactive oxygen species and cell death by pyroptosis. ${ }^{44}$

Our study has also revealed that the expression levels of several type 2 helper T-cell cytokines were higher than those of type 1 helper T-cell cytokines in the neural parenchyma of ZIKV-infected patients, including IL-4, IL-10, TGF- $\beta$, and IL-33. In cases of ZIKV-associated microcephaly, these cytokines are suggested to be involved in anti-inflammatory responses, tissue repair, and the differentiation of glial cells (primarily M2 microglia). ${ }^{45,46}$ However, the pleiotropic behavior of these cytokines means that they can also induce an immunosuppressive response, and both IL-4 and IL-10 are classically described as inhibitors of a neuroinflammatory response. ${ }^{45-47}$ Recently, neurologic complications and congenital CNS abnormalities have been linked to ZIKV infection, although higher levels of IL-4 and IL-10 were observed in patients with milder disease outcomes. ${ }^{47}$ Further characterization of cytokine expression in these cases indicated that natural killer cells, IL-18, interferon- $\gamma$, and IL-10 act synergistically to protect the CNS against ZIKV-induced neuropathogenesis. ${ }^{47}$ Finally, TGF- $\beta$ is a powerful inducer of apoptosis and inhibits the inflammatory response. During yellow fever virus and DENV infections, extensive lesions in zone 2 of the hepatic parenchyma are characterized by elevated expression of TGF- $\beta$ in apoptotic cells. ${ }^{48,49}$ These findings indicate that apoptosis induced by TGF- $\beta$ is directly 
associated with flavivirus-induced pathogenesis. We hypothesize that apoptosis triggered by TGF- $\beta$ during ZIKV infection of the neural parenchyma can be induced by the activation of SMADs, caspase 8 , and caspase $3 .^{50,51}$

In particular, our analysis of type 2 helper T-cell markers suggested that IL-33 is a potentially important cytokine during ZIKV infection. In several areas of the cerebral cortex, strong IL-33 immunostaining was found in apoptotic glial cells and neurons, as well as areas of neuronal necrosis. We, therefore, suggest that IL-33 should be further studied to fully understand its role during ZIKV-induced neuropathogenesis. Previously, IL-33 signaling has been shown to be essential for attenuating viral-induced encephalitis during West Nile virus infection by down-regulating inducible nitric oxide synthase expression in the CNS. ${ }^{52}$ In this same study, the pleiotropism attributed to IL-33 indicated that it might directly regulate the production of caspase 3 by activation of the IL-1 receptor-like 1 receptor (alias ST2). ${ }^{52}$ A similar process may, therefore, also occur during ZIKV infection.

In summary, our study has confirmed the complexity of the in situ immune response to ZIKV, although the data suggest that apoptosis in neural parenchyma lesions may contribute significantly to the pathogenesis of fatal ZIKV microcephaly cases. Additional in vitro and in vivo studies are, therefore, required to fully establish the relationship between the immune response, apoptosis, and pathology of ZIKV in the CNS.

\section{Acknowledgments}

We thank the staff of the Department of Pathology at the Evandro Chagas Institute for assistance, especially Valter M. Campos, Orlando P. Amador Neto, and Maria L.G. Lima and the staff of the Department of Arbovirology and Hemorrhagic Fevers for technical support.

J.R.S, R.S.S.A, J.A.S.Q, and P.F.C.V conceived the study; A.J.M.F and M.T.F.A furnished samples; J.R.S, M.T.F.A, A.J.M.F, A.C.R.C, B.C.B.V, B.H.B.V, J.O.C., L.C.M, L.M.N.C, and J.A.S.Q performed tests; J.R.S, R.S.S.A, C.S.O, J.A.S.Q, and P.F.C.V analyzed results; P.F.C.V financed the study; J.R.S, R.S.S.A, J.A.S.Q, and P.F.C.V wrote the article; all authors revised the article and agreed with submission.

\section{Supplemental Data}

Supplemental material for this article can be found at https://doi.org/10.1016/j.ajpath.2018.07.009.

\section{References}

1. Azevedo RSS, de Sousa JR, Araujo MTF, Martins Filho AJ, de Alcantara BN, Araujo FMC, Queiroz MGL, Cruz ACR, Vasconcelos BHB, Chiang JO, Martins LC, Casseb LMN, da
Silva EV, Carvalho VL, Vasconcelos BCB, Rodrigues SG, Oliveira CS, Quaresma JAS, Vasconcelos PFC: In situ immune response and mechanisms of cell damage in central nervous system of fatal cases microcephaly by Zika virus. Sci Rep 2018, 8:1

2. Dick GW, Kitchen SF, Haddow AJ: Zika virus, I: isolations and serological specificity. Trans R Soc Trop Med Hyg 1952, 46: 509-520

3. Desclaux A, de Lamballerie X, Leparc-Goffart I, Vilain-Parcé A, Coatleven F, Fleury H, Malvy D: Probable sexually transmitted Zika virus infection in a pregnant woman. N Engl J Med 2018, 378: $1458-1460$

4. Miner JJ, Diamond MS: Zika virus pathogenesis and tissue tropism. Cell Host Microbe 2017, 21:134-142

5. Zorrilla CD, García I, García Fragoso L, De La Vega A: Zika virus infection in pregnancy: maternal, fetal, and neonatal considerations. J Infect Dis 2017, 216 Suppl 10:S891-S896

6. Duffy MR, Chen TH, Hancock WT, Powers AM, Kool JL, Lanciotti RS, Pretrick M, Marfel M, Holzbauer S, Dubray C, Guillaumot L, Griggs A, Bel M, Lambert AJ, Laven J, Kosoy O, Panella A, Biggerstaff BJ, Fischer M, Hayes EB: Zika virus outbreak on Yap Island, Federated States of Micronesia. N Engl J Med 2009, 360:2536-2543

7. Musso D, Nilles EJ, Cao-Lormeau VM: Rapid spread of emerging Zika virus in the Pacific area. Clin Microbiol Infect 2014, 20 O595-O596

8. Cao-Lormeau VM, Roche C, Teissier A, Robin E, Berry AL, Mallet HP, Sall AA, Musso D: Zika virus, French Polynesia, South Pacific, 2013. Emerg Infect Dis 2014, 20:1085-1086

9. Jouannic JM, Friszer S, Leparc-Goffart I, Garel C, EyrolleGuignot D: Zika virus infection in French Polynesia. Lancet 2016, 387:1051-1052

10. Hennessey M, Fischer M, Staples JE: Zika virus spreads to new areasregion of the Americas, May 2015-January 2016. MMWR Morb Mortal Wkly Rep 2016, 65:55-58

11. Heukelbach J, Alencar CH, Kelvin AA, de Oliveira WK, Pamplona de Góes Cavalcanti L: Zika virus outbreak in Brazil. J Infect Dev Ctries 2016, 10:116-120

12. Araujo LM, Ferreira ML, Nascimento OJ: Guillain-Barré syndrome associated with the Zika virus outbreak in Brazil. Arq Neuropsiquiatr 2016, 74:253-255

13. Azevedo RS, Araujo MT, Martins Filho AJ, Oliveira CS, Nunes BT, Cruz AC, Nascimento AG, Medeiros RC, Caldas CA, Araujo FC, Quaresma JA, Vasconcelos BC, Queiroz MG, da Rosa ES, Henriques DF, Silva EV, Chiang JO, Martins LC, Medeiros DB, Lima JA, Nunes MR, Cardoso JF, Silva SP, Shi PY, Tesh RB, Rodrigues SG, Vasconcelos PF: Zika virus epidemic in Brazil, I: fatal disease in adults: clinical and laboratorial aspects. J Clin Virol 2016, 85:56-64

14. Ali A, Wahid B, Rafique S, Idrees M: Advances in research on Zika virus. Asian Pac J Trop Med 2017, 10:321-331

15. Meertens L, Labeau A, Dejarnac O, Cipriani S, Sinigaglia L, BonnetMadin L, Le Charpentier T, Hafirassou ML, Zamborlini A, CaoLormeau VM, Coulpier M, Missé D, Jouvenet N, Tabibiazar R, Gressens P, Schwartz O, Amara A: Axl mediates ZIKA virus entry in human glial cells and modulates innate immune responses. Cell Rep 2017, 18:324-333

16. Chen J, Yang YF, Yang Y, Zou P, Chen J, He Y, Shui SL, Cui YR, Bai R, Liang YJ, Hu Y, Jiang B, Lu L, Zhang X, Liu J, Xu J: AXL promotes Zika virus infection in astrocytes by antagonizing type I interferon signalling. Nat Microbiol 2018, 3:302-309

17. Teng Y, Liu S, Guo X, Liu S, Jin Y, He T, Bi D, Zhang P, Lin B An X, Feng D, Mi Z, Tong Y: An integrative analysis reveals a central role of P53 activation via MDM2 in Zika virus infection induced cell death. Front Cell Infect Microbiol 2017, 7:327

18. Ho CY, Ames HM, Tipton A, Vezina G, Liu JS, Scafidi J, Torii M, Rodriguez FJ, du Plessis A, DeBiasi RL: Differential neuronal 
susceptibility and apoptosis in congenital Zika virus infection. Ann Neurol 2017, 82:121-127

19. Shrestha B, Diamond MS: Fas ligand interactions contribute to CD $8+$ T-cell-mediated control of West Nile virus infection in the central nervous system. J Virol 2007, 81:11749-11757

20. Tsao CH, Su HL, Lin YL, Yu HP, Kuo SM, Shen CI, Chen CW, Liao CL: Japanese encephalitis virus infection activates caspase-8 and -9 in a FADD-independent and mitochondrion-dependent manner. J Gen Virol 2008, 89:1930-1941

21. Faizan MI, Abdullah M, Ali S, Naqvi IH, Ahmed A, Parveen S: Zika virus-induced microcephaly and its possible molecular mechanism. Intervirology 2016, 59:152-158

22. Tesh RD: An improved method for the isolation and identification of dengue viruses, using mosquito cell cultures. Am J Trop Med Hyg 1979, 6:1053-1059

23. Faye O, Faye O, Dupressoir A, Weidmann M, Ndiaye M, Alpha Sall A: One-step RT-PCR for detection of Zika virus. J Clin Virol 2008, 43:96-101

24. Lanciotti RS, Kosoy OL, Laven JJJ, Velez O, Lambert AJ, Johnson AJ: Genetic and serologic properties of Zika virus associated with an epidemic, Yap State, Micronesia, 2007. Emerg Infect Dis 2008, 14:1232-1239

25. Hsu SM, Raine L: Protein A, avidin, and biotin in immunohistochemistry. J Histochem Cytochem 1981, 29:1349-1353

26. Culshaw A, Mongkolsapaya J, Screaton GR: The immunopathology of dengue and Zika virus infections. Curr Opin Immunol 2017, 48: $1-6$

27. Ritter JM, Martines RB, Zaki SR: Zika virus: pathology from the pandemic. Arch Pathol Lab Med 2017, 141:49-59

28. Chimelli L, Melo ASO, Avvad-Portari E, Wiley CA, Camacho AHS, Lopes VS, Machado HN, Andrade CV, Dock DCA, Moreira ME, Tovar-Moll F, Oliveira-Szejnfeld PS, Carvalho ACG, Ugarte ON, Batista AGM, Amorim MMR, Melo FO, Ferreira TA, Marinho JRL, Azevedo GS, Leal JIBF, da Costa RFM, Rehen S, Arruda MB, Brindeiro RM, Delvechio R, Aguiar RS, Tanuri A: The spectrum of neuropathological changes associated with congenital Zika virus infection. Acta Neuropathol 2017, 133:983-999

29. Smith DR, Hollidge B, Daye S, Zeng X, Blancett C, Kuszpit K, Bocan T, Koehler JW, Coyne S, Minogue T, Kenny T, Chi X, Yim S, Miller L, Schmaljohn C, Bavari S, Golden JW: Neuropathogenesis of Zika virus in a highly susceptible immunocompetent mouse model after antibody blockade of type I interferon. PLoS Negl Trop Dis 2017, 11:e0005296

30. Winkler CW, Myers LM, Woods TA, Messer RJ, Carmody AB, McNally KL, Scott DP, Hasenkrug KJ, Best SM, Peterson KE: Adaptive immune responses to Zika virus are important for controlling virus infection and preventing infection in brain and testes. J Immunol 2017, 198:3526-3535

31. Wang Y, Lobigs M, Lee E, Müllbacher A: Exocytosis and Fas mediated cytolytic mechanisms exert protection from West Nile virus induced encephalitis in mice. Immunol Cell Biol 2004, 82:170-173

32. Ghosh Roy S, Sadigh B, Datan E, Lockshin RA, Zakeri Z: Regulation of cell survival and death during Flavivirus infections. World J Biol Chem 2014, 5:93-105

33. Okamoto T, Suzuki T, Kusakabe S, Tokunaga M, Hirano J, Miyata Y, Matsuura Y: Regulation of apoptosis during flavivirus infection. Viruses 2017, 9:243

34. Benazzato C, Almeida N, Pignatari GC, Romero S, Polonio CM, Cunha I, Freitas CL, Brandão WN, Rossato C, Andrade DG, Faria Dde P, Garcez AT, Buchpigel CA, Braconi CT, Mendes E, Sall AA, Zanotto PM, Peron JP, Muotri AR, Beltrão-Braga PC: The Brazilian Zika virus strain causes birth defects in experimental models. Nature 2016, 534:267-271

35. Manangeeswaran M, Ireland DD, Verthelyi D: Zika (PRVABC59) infection is associated with $\mathrm{T}$ cell infiltration and neurodegeneration in CNS of immunocompetent neonatal C57B1/6 mice. PLoS Pathog 2016, 12:e1006004

36. Ofengeim D, Yuan J: Regulation of RIP1 kinase signalling at the crossroads of inflammation and cell death. Nat Rev Mol Cell Biol 2013, 14:727-736

37. Mocarski ES, Upton JW, Kaiser WJ: Viral infection and the evolution of caspase 8-regulated apoptotic and necrotic death pathways. Nat Rev Immunol 2011, 12:79-88

38. Arjona A, Ledizet M, Anthony K, Bonafé N, Modis Y, Town T, Fikrig E: West Nile virus envelope protein inhibits dsRNA-induced innate immune responses. J Immunol 2007, 179:8403-8409

39. Sun P, Kochel TJ: The battle between infection and host immune responses of dengue virus and its implication in dengue disease pathogenesis. ScientificWorldJournal 2013, 2013:843469

40. Limonta D, Torrentes-Carvalho A, Marinho CF, Azeredo EL, Souza LJ, Motta-Castro AR, da Cunha RV, Kubelka CF, Nogueira RM, de-Oliveira-Pinto LM: Apoptotic mediators in patients with severe and non-severe dengue from Brazil. J Med Virol 2014, 86:1437-1447

41. Ashhurst TM, Vreden CV, Munoz-Erazo L, Niewold P, Watabe K, Terry RL, Deffrasnes C, Getts DR, Cole King NJ: Antiviral macrophage responses in flavivirus encephalitis. Indian J Med Res 2013, 138:632-647

42. Murray CL, Skelly DT, Cunningham C: Exacerbation of CNS inflammation and neurodegeneration by systemic LPS treatment is independent of circulating IL-1 $\beta$ and IL-6. J Neuroinflammation 2011, 8:50

43. Olmos G, Lladó J: Tumor necrosis factor alpha: a link between neuroinflammation and excitotoxicity. Mediators Inflamm 2014, 2014:861231

44. Tricarico PM, Caracciolo I, Crovella S, D’Agaro P: Zika virus induces inflammasome activation in the glial cell line U87-MG. Biochem Biophys Res Commun 2017, 492:597-602

45. Tang $\mathrm{Y}$, Le W: Differential roles of $\mathrm{M} 1$ and $\mathrm{M} 2$ microglia in neurodegenerative diseases. Mol Neurobiol 2016, 53:1181-1194

46. Cherry JD, Olschowka JA O, Banion MK: Neuroinflammation and M2 microglia: the good, the bad, and the inflamed. J Neuroinflamm 2014, 11:98

47. Kam YW, Leite JA, Lum FM, Tan JJL, Lee B, Judice CC, Teixeira DAT, Andreata-Santos R, Vinolo MA, Angerami R, Resende MR, Freitas ARR, Amaral E, Junior RP, Costa ML, Guida JP, Arns CW, Ferreira LCS, Rénia L, Proença-Modena JL, Ng LFP1, Costa FTM; Zika-Unicamp Network: Specific biomarkers associated with neurological complications and congenital central nervous system abnormalities from Zika virus-infected patients in Brazil. J Infect Dis 2017, 216:172-181

48. Quaresma JA, Barros VL, Pagliari C, Fernandes ER, Guedes F, Takakura CF, Andrade HF Jr, Vasconcelos PF, Duarte MI: Revisiting the liver in human yellow fever: virus-induced apoptosis in hepatocytes associated with TGF-beta, TNF-alpha and NK cells activity. Virology 2006, 345:22-30

49. Pagliari C, Quaresma JA, Fernandes ER, Stegun FW, Brasil RA, de Andrade HF Jr, Barros V, Vasconcelos PF, Duarte MI: Immunopathogenesis of dengue hemorrhagic fever: contribution to the study of human liver lesions. J Med Virol 2014, 86:1193-1197

50. Schuster N, Krieglstein K: Mechanisms of TGF-beta-mediated apoptosis. Cell Tissue Res 2002, 307:1-14

51. Spender LC, O'Brien DI, Simpson D, Dutt D, Gregory CD, Allday MJ, Clark LJ, Inman GJ: TGF-beta induces apoptosis in human B cells by transcriptional regulation of BIK and BCL-XL. Cell Death Differ 2009, 16:593-602

52. Franca RF, Costa RS, Silva JR, Peres RS, Mendonça LR, Colón DF, Alves-Filho JC, Cunha FQ: IL-33 signaling is essential to attenuate viral-induced encephalitis development by downregulating iNOS expression in the central nervous system. J Neuroinflammation 2016 , 13:159 